\title{
The Examination Impact of Speculation and Profit Sharing to the Mudaraba Deposits in Indonesia Islamic Banks
}

\author{
Ruhadi \\ Politeknik Negeri Bandung \\ ruhadi@polban.ac.id

\section{Setiawan} \\ Politeknik Negeri Bandung \\ setiawan@polban.ac.id
}

\begin{abstract}
This study aims to identify the motives of customers in investing their funds in Islamic banks in Indonesia. In general, there are two motives, speculation and investment, and these two motives want to be identified in this study. The data used in this study are financial reports from Islamic banks collected from OJK statistics, for the period 2013 to 2017. The analytical tool used in this study is multiple regression which will relate the dependent variable of mudaraba deposits as a representation of savings in Islamic banks with two independent variables consisting of stock prices to identify stock returns as a representation of the motive of speculation as well as profit sharing or ratio which is a representation of investment motives. The results showed that stock returns simultaneously did not influence the changes in mudaraba deposits. Nevertheless the results of the partial statistical analysis indicate that the RS has a negative and significant influence on mudaraba savings. The next finding is that profit and loss sharing has a positive and statistically significant simultaneous effect on mudaraba savings in Islamic banks. Based on the results of this study, it is expected to become a reference for Islamic bank managers in targeting prospective customers. Islamic banks need to highlight investment products so that more prospective customers are interested in joining Islamic banks.
\end{abstract}

Kata Kunci Islamic Bank, Mudaraba Deposits, Speculation, Profit Sharing,

\section{INTRODUCTION}

The findings of Arshad \& Nurfadilah (2017)'s research show that conventional interest rates and non-performing financing (NPF) have a negative relationship with changes in mudaraba deposits, while bank returns and reserves have a positive and significant relationship with changes in mudaraba deposits in Indonesia and in Malaysia. On the other hand, studies from Ahmad \& Haron (2002) indicate that customers who place their deposits on savings and investment are triggered by profit motives. The condition of the theory of benefit maximization among Muslim customers is confirmed by the negative relationship between the interest rates of conventional banks and the amount of interestfree deposits (Haron et al., 1999). 
The first Sharia bank was spearheaded by the local savings bank Mit Gamhr in 1963 in the city center of the province in the Egyptian Nile River Delta. Currently there are more than 200 non-interest financial institutions operating in 40 countries that provide services that are compatible with services as provided by conventional banks. In 1985 the system mobilized approximately $\$ 5$ billion in funds which have now increased to $\$ 80$ billion. Conventional Western banks such as City Bank, JP Morgan, Deutsche Bank, ABN Amro and American Express Bank began to introduce non-interest product services to customers. Like conventional banks, Islamic banks are very dependent on depositors' funds as the main source of funds. Bank Syariah Indonesia has $75 \%$ of total debt and equity deposits at the end of 2017. Since depositor's funds are the main source of funding, it is important for the management of Islamic Banks to find out the factors that influence customers' decisions in saving their money in Islamic banks. The hope of this study can show the extent of religion as a factor of choice for customers in choosing Islamic banks as a place to deposit their funds in Indonesia. Several studies have been carried out in Sudan and Turkey showing that religion is not the main reason for customers in choosing Islamic banks (Erol and El-Bdour, 1989) that the same study was conducted in Malaysia and Singapore to find religion and profits as customer reasons in maintaining relations with Islamic banks (Haron et al, 1994, Gerrad \& Cunningham, 1997).

Leeds (1992) in its study revealed that service quality and professional attitudes can increase customer satisfaction and these two attitudes will eventually result in a decrease in the number of customers who move elsewhere. They also found that nearly $40 \%$ of customers moved to other banks because of poor service quality. Haron et al. (1994) analyzes 3 basic factors that are important for choosing a bank, namely efficiency, speed and kinship or friendliness. The same study conducted by Naser et al in Jordan found that 70 percent of respondents chose Islamic banks because of religious factors.

Hegazy (1995)'s research found that in Egypt, customers based on religion and Islamic law chose and used Islamic banking services but they still compared the services and products of both banks and decided to choose a bank. Poor service will cause dissatisfaction with customers and they will easily move to other banks (Levesque and McDougall, 1996). Gerrard \& Cunninggham (1997) indicated through his study that clients in Singapore were aware and ready to compromise in choosing Islamic banks. Metawa and Almossawi (1998) conducted a study of the customer approach in choosing a bank and they concluded that Islamic principles were an important factor. Based on these findings it can be concluded that the customer chose a sharia bank because of two things, namely religious factors and economic factors.

This study intends to identify the motives of customers that influence mudaraba deposits from two motive categories, namely speculation and profit sharing. As is known from sharia business principles that speculation is prohibited while investment is a motive that is permissible and even highly recommended, so it is expected to have an impact on more productive activities and can provide maximum benefits at the opening of broader employment opportunities and increased welfare people. Thus it is expected that this study will reach the goal of finding the influence of the motive of speculation and profit sharing 
on mudaraba deposits on Islamic banks. Given that mudaraba deposits are deposits that dominate enough in third party deposits in Islamic banks in Indonesia (Setiawan, 2018). According to records from Otoritas Jasa Keuangan (Financial Services Authority) mudaraba deposits in the period 2011-2015 increased from 57.9 percent to 62.3 percent (Otoritas Jasa Keuangan, 2016). It is hoped that the results of this study can provide an overview of the motives that become the basis of customers in choosing Islamic banks as a place for them to save their funds so that Islamic banks can determine the right strategy in anticipating their customers' attitudes in order to continue to source appropriate funds for sharia bank business development to front. Thus, a research question can be asked what are the motives of Islamic bank customers in mudarabah-based savings?

\section{LITERATURE REVIEW}

The interest rate is one indicator of economic factors that is important in explaining saving behavior from individuals in conventional banks. Savings as a classical economist convey is a function of the interest rate. A higher interest rate will result in a lot of money being saved. When the interest rate is high, people will flock to save to get a higher utility. Based on benefit maximization, the interest rate is the center of attention of modern consumer behavior theory and is the present value of all-time resources. For savers, the increase in interest rates will have a broad effect on two things; income effects that will result in increased current consumption and substitution effects which result in a decrease in current consumption (Hadjimatheou, 1987; Taylor, 1999; El-Seoud, 2014).

Keynes (1936) argues that quantitatively the level of interest is believed in the long run. The rate of change can lead to changes in social habits, including subjective tendencies to save. Friedman (1957) in his neo-classical consumption function analysis revealed that the main variable determining the average consumption trend is the interest rate, namely the relative dispersion of the transitory component for consumption and income, the welfare ratio of income, age and composition of consumer units. Each difference in deposit types available at conventional banks provides a different interest rate for each depositor. In general, the long maturity of a deposit will give a greater yield to depositors. Deposits generally pay a higher interest rate to customers who save funds longer than customers who deposit funds in the bank in the short term.

Banking people have learned that determining the deposit value can be used to sharpen the types of customers based on the best services from each bank. Changes in the value of deposits have an effect not only spread between bank loan rates and deposit interest rates, but also customer accounts, even affecting bank growth and profit margins (Edmister, 1982). As Rose pointed out, the determination of deposit prices is very well used to protect and increase bank profitability, rather than to invite more customers and to win market share from competitors. Conversely when a new deposit plan is introduced, this is very interesting and the best opportunity to succeed depends on the customer who has become the bank's depositor.

\section{Relationship Between Savings and Stock Returns}

The increase in the number of deposits in conventional banks is generally due to an increase in deposit rates. This is related to the theory which reveals that the principle of 
benefit maximization will have an impact on customers to maximize profits on each fund invested (Keynes, 1936). However, in Islamic banks motiv to get stock returns or speculation is something that is forbidden because it enters into usury and speculation as stated in Surah Ali Imron verse 130 as follows:

"Hi the people who believe to Allah, do not eat usury by multiplying and fear Allah so that you may have good fortune. Take care of yourself from the fire of hell provided for those who disbelieve. (Surah Ali Imron, QS (3), 130)

Referring to the argument it is clear that interest as one of the elements of usury is prohibited, thus giving the consequence that this motive should not be allowed in Islam. Thus in fact this should not appear in a business based on syar'i. While others which are also prohibited in sharia business are gambling and speculation as QS Al'Maidah 90 follows:

"Hi the people who believe to Allah, actually drink khamar, gamble sacrifices for idols, draw fate with arrows, including acts of shaitan. So stay away from those deeds so that you get good luck." (QS: Al Maidah 90)

This paragraph provides an explanation that speculation or raffling of fate is not permitted in sharia business. Thus, in applying the sharia business the element of chancy is prohibited.

\section{Relationship Between Savings and Profit Sharing}

In particular because Islamic banks do not tolerate interest, depositors in this bank will generally save funds with the aim of providing social benefits, where the funds they save will be used in the favor of Allah, so that they do not emphasize economic interests but on a balanced distribution. between risk and yield (profit sharing). So that the right form of compensation in the investment is in the form of profit sharing. In syar'i it is possible that we invest our assets in order to provide wider benefits to the ummah in productive activities to produce halal goods and services and in a way that is justified by syar'i. As QS: Al'Baqoroh, 261), the following:

"The parable (which is spent by) those who spend their wealth in the way of Allah is similar to a seed that grows seven points in each one hundred seeds, Allah multiplies (reward) for whom he wants and Allah is vast (gift-Him), omniscient." (Al'Baqoroh 261)

This verse gives an explanation that if the property is managed in the way of Allah, it is permissible and even promised to be multiplied by Allah, thus investment is permissible in sharia. Therefore the implementation of sharia business should show business practices that prioritize mutually beneficial transactions and collectively share the risks when the business is carried out in a loss. The manifestation of this is that sharia business transactions are reflected in the form of profit sharing from borrowing and borrowing with interest.

\section{RESEARCH METHODOLOGY}

This research approach is secondary data analysis with associative methods. Data is collected from the Financial Services Authority (OJK) statistics, in the form of financial statements for the last five years from 2013 to 2017. As explained in the background 
above, most deposits in Islamic banks are in mudaraba deposits. These third party deposits in Islamic banks are thought to be divided into two categories, namely speculation and profit sharing. In the above theoretical review the motives reflected by customers can be categorized into two categories, namely the first category of speculation or usury which in this study will be proxied by stock returns obtained from today's stock price (Pt) minus yesterday's stock price (Pt- 1) divided by yesterday's stock price (Pt-1), and formulated in formula (Pt - Pt-1) / Pt-1. Second is the investment category which in this study will be proxied by profit sharing, namely profit sharing from profits obtained in the form of a ratio that is in accordance with the net difference between income and expenditure. While the dependent variable will be proxied by savings or mudaraba deposits. As for data analysis using multiple linear regression.

\section{RESULTS}

The research data is taken from the Financial Services authority statistics (OJK) from 2013 to 2017 with detailed monthly data in that period so that the observed data amounts to 42 months. Of the three observed variables can be observed descriptively as follows.

The highest mudaraba savings was achieved in 2017 for the December period of Rp.7,033 billion and the lowest was achieved in the March 2014 period of Rp.1,993 billion. While for the highest profit sharing reached the December 2017 period of Rp.480.604 million and the lowest reached in 2014 in June amounting to Rp.1,140 million. The maximum stock return achieved in 2017 in December was 32.31 percent and the lowest was achieved in November 2016 of minus 21.57 percent.

The analysis used to identify the effects of speculation and profit sharing is used regression with the formulation below using SPSS version 18, the results of processing data can be seen as follows:

Tabel 1. Result of Regression

\begin{tabular}{|c|c|c|c|}
\hline Model & $\begin{array}{c}\text { Standardiced } \\
\text { Coefficients }\end{array}$ & $\mathbf{t}$ & Sig \\
\hline 1 (Constant) & Deta & 13,536 & 0,000 \\
\hline RS & $-0,126$ & 0,297 & 0,297 \\
\hline $\mathrm{BH}$ & 0,607 & 5,097 & 0,000 \\
\hline
\end{tabular}

A Dep. Variable MUDH

The results of the data above show that mudaraba depositss are statistically influenced positively and significantly by profit sharing $(\mathrm{BH})$, but stock returns (RS), do not have a significant effect on the growth of mudaraba deposits.

Referring to the results of the analysis, it can be said that mudaraba deposits in Islamic banks are not influenced by stock returns, meaning that Islamic bank customers who save their funds in mudaraba do not have the motive of speculation. This is in line with sharia business principles that prohibit speculation, whereas mudaraba deposits are influenced positively and significantly by profit sharing. This finding is in accordance with sharia 
business principles that business cooperation agreements in sharia are permitted on the basis of profit sharing rather than usury and speculation. In relative terms, mudaraba deposits in Islamic banks will increase in line with the motives of customers who only hope for profit sharing rather than speculation. Thus, it can be said that the motives of sharia bank customers have been on the right path based on sharia, namely saving money with a profit sharing motive which is justifiably in the sharia business;

"There are three things that contain blessings: buying and selling not in cash, muqaradhah (mudaraba), and mixing fine wheat with coarse wheat (jemawut) for household use, not for sale." (Hadist, from Ibnu Majah)

This finding has also been strengthened by the Fatwa of the National Sharia Council No. 38 / DSN-MUI / X / 2002 concerning interbank mudaraba investment certificates (IMA certificates) as follows:

General Provisions, namely: (i) Interbank interest-based investment certificates are not justified according to sharia; (ii) Investment certificates based on the Mudaraba agreement, called the Interbank.

Mudaraba Investment Certificate (IMA), are justified according to sharia. The findings from the results of the analysis simultaneously also explain that changes in stock return (RS) and profit sharing $(\mathrm{BH})$ factors can statistically contribute to explaining changes in mudaraba deposits as can be seen from the results of the following analysis:

Tabel 1. Result of Regression

\begin{tabular}{rl|r|r|r|}
\hline Model & R & R Square & $\begin{array}{c}\text { Adjusted } \\
\text { R Square }\end{array}$ & $\begin{array}{c}\text { Sig F } \\
\text { Change }\end{array}$ \\
\hline 1 & 0,661 & 0,437 & 0,412 & 0,000 \\
\hline
\end{tabular}

By observing discriminant factors ( $\mathrm{R}$ Square) it can be said that the independent variable (stock return and profit sharing) can statistically explain changes in mudaraba deposits by 43.7 percent and the remainder explained by other factors. Nevertheless partially it can be found that statistically stock returns (RS) have a negative and significant effect on mudaraba deposits as can be seen below:

Tabel 2. Result of Regression

\begin{tabular}{|c|r|r|r|}
\hline \multirow{2}{*}{ Model } & $\begin{array}{c}\text { Standardiced } \\
\text { Coefficients }\end{array}$ & \multirow{2}{*}{ t } & \multicolumn{1}{l|}{ Sig } \\
\cline { 2 - 2 } & Beta & & 0,000 \\
\hline 1 (Constant) & & 24,056 & 0,020 \\
\hline RS & $-0,334$ & $-2,406$ & \\
\hline
\end{tabular}

a dependent variable MUDH

In a deep analysis of partial analysis, it can be seen that stock returns (RS) have a negative and significant effect on mudaraba deposits (coefficient Sig. $=0.020$ ). This indicates that partially decreasing statistics from speculation factors from customers of Islamic Banks 
will have an impact on increasing mudaraba deposits. This indicates that when customer speculation decreases there will be an increase in mudaraba, this condition is in line with sharia business principles that prohibit speculation or chancy. It can be said that the motives of sharia bank customers in depositing funds in Islamic banks are not motivated by speculation, even other indications show that when speculation decreases it has an impact on increasing mudaraba deposits in Islamic banks. In other words, the motive for speculation on sharia bank customers is likely to have declined and turned into a more justified motive in syar'i, namely with the motive of profit sharing. The profit sharing motive of customers on Islamic banks shows, as a factor that has a positive and significant effect on changes in mudaraba deposits in Islamic banks. This condition indicates that Islamic bank customers have an investment/profit sharing motive in depositing their funds in Islamic banks. In other words, the customer is in the right condition in accordance with sharia business principles as is the Fatwa of the National Sharia Council No. 38 / DSN-MUI / X / 2002.

\section{CONCLUSIONS}

Based on the results of the analysis and discussion above, it can be concluded statistically that speculation in the form of a motive to seek stock returns simultaneously does not have an impact on changes in mudaraba deposits on Islamic banks, although partially it can be found that speculation has a negative and significant effect on mudaraba savings in Islamic banks. By looking at bank customers' motives as can be identified in the findings, anticipation that needs to be considered is how to channel the correct motives syar'i by continuing to provide products that allow customers to save their funds in aspects of Islamic investment, so that funds can be channeled to more productive and give maximum benefit to the economic improvement of the people as a whole.

\section{REFERENCES}

Ahmad, N \& Haron, S. (2002). Perceptions of Malaysian Corporate Customer Toward Islamic Banking Product and Service. International Journal of Islamic Financial Service. Vol. 3 No. 4.

Arshad, N.C. \& Nurfadilah, D. (2017). The Factors Influencing the Changes of Deposit in Islamic Bank: Comparative Study between Malaysia and Indonesia. Journal of Islamic Banking and Finance, Desember 2017, 5(2), 37-46

Edmister, R. O. (1982). Margin Analysis for Consumer Deposit Interest Rate Policy. Journal of Bank Research, Autumn 1982, 179-84

El-Seoud, Mohamed Sayed Abou. (2014). The Effect of Interest Rate, Inflation Rate and GDP on National savings Rate. Global Journal of Commerce \& Management Perspective, 3(3), 1-7

Erol, C., \& El-Bdour, R. (1989). Attitude, Behaviour and Patronage Factors of bank Customers towards Islamic Banks. International Journal of Bank Marketing, 7(6), 31-39

Friedman, M. (1957). A Theory of the Consumption Function. Princeton: Princeton University Press 
Gerrard, P. And Cunningham J.B. (1997). Islamic Banking: A Study in Singapore. International Journal of Bank Marketing, 15(6), 204-216

Hadjimatheou, G. (1987). Consumer Economics After Keynes. Wheatsheaf Books, Sussex, Great Britai

Haron, S, Ahmad, N. \& Planisek, S. L. (1994). Bank Patronage Factors of Muslim and Non-Muslim Customers. International Journal of Bank Marketing, 12(1), 32-40.

Haron, S \& Ahmad, N. (1999). The Effects of Conventional Interest Rate and Rate of Profit on Funds deposited With Islamic Banking System in Malaysia. International Journal of Islamic Financial Services, 1(4)

Haron, S. Ahmad, N., and Planisek., S. (1994). Bank Patronage Factors of Muslim and Non-Muslim Customer. International Journal of Bank Marketing, 12(1), 32-40

Hegazy, I. (1995). An Empirical Comparative Study Between Islamic and Commercial Banks' selection criteria in Egypt. International Journal of Commerce \& Management. 5(3), 46-61.

Keynes, J.M. (1936). The General Theory of Employments, Interest and Money. London: Macmillan

Leeds B., (1992). 'Mystery Shopping Offers' clues to Quality Service, Bank Marketing, 24(11), November, 24-27

Levesque, T. and McDougall, G.H.G. (1996). Determinants of customer satisfaction in retail banking. International Journal of Bank Marketing, 14(7),12-20

Metawa, S.A., and Almossawi, M. (1998). Banking Behaviour of Islamic Bank Customer: Persfectives and Implications. International Journal of Bank Marketing, 16(7), 299-313

Otoritas Jasa Keuangan. (2016). Statistik Perbankan Indonesia - Desember 2015. https://www.ojk.go.id/id/kanal/syariah/data-dan-statistik/statistik-perbankansyariah/Documents/Pages/Statistik-Perbankan-Syariah_-Desember-2015/SPS Desember 2015.pdf

Setiawan, S. (2018). Determinan Penentu Pertumbuhan Dana Pihak Ketiga Perbankan Syariah di Indonesia. Jurnal Maps (Manajemen Perbankan Syariah), 1(2), 1-9.

Taylor, Mark P. (1999). Real Interest Rates and Macroeconomic Activity. Oxford Review of Economic Policy, 15(2), 95-113. Retrieved October 10, 2020, from http://www.jstor.org/stable/23606914 